Revista da Faculdade Mineira de Direito | V.23 N.45|

\title{
ACCESS TO JUSTICE: Legal concept and characterization
}

\author{
ACCESSO ALLA GIUSTIZLA: Concetto legale e caratterizzazione
}

Paulo Márcio Cruz'
UNIVALI

Bruno Makowiecky Salles

UNIVALI

\begin{abstract}
:
What should be understood, contemporaneously, by Access to Justice? This paper addresses the challenge of answering this question by describing the main elements that portray the stage of development of the theme in Legal Science. With no pretension to exhaust the subject, considering its scope and complexity, we seek to situate Access to Justice in the contemporary scene and present the approaches commonly attributed to it, providing the methodological and terminological clarifications necessary for a proper understanding. In this context, considerations are made about perspectives classified as legal-procedural and democratic-institutional, as well as the conceptions, included in the universe of Access to Justice (lato sensu), Access to the Judiciary and Access to Rights.
\end{abstract}

Keywords:

Access to Justice; Rights; Democratic Institution.

\section{Riassunto:}

Che cosa andrebbe capito, nella contemporaneità, a riguardo dell' Accesso alla Giustizia? Questo articolo affronta la sfida di rispondere a questa domanda descrivendo gli elementi principali che incorniciano lo stadio di sviluppo del tema nelle Scienze Giuridiche. Senza alcuna pretesa di essere esaustivi a riguardo della materia, considerato lo scopo e la complessità della medesima, si cercherà di situare l' Accesso alla Giustizia nella scena contemporanea e presentare gli approcci comunemente attribuiti a questa, fornendo i chiarimenti metodologici e terminologici necessari per una corretta comprensione. In questo contesto, le considerazioni verranno fatte a riguardo di prospettive qualificate come legali-procedurali e democratiche - istituzionali, così come anche le concezioni, incluse nell' universo dell' Accesso alla Giustizia (lato sensu), Accesso alla Magistratura e Accesso ai Diritti.

Parole Chiave:

Accesso alla Giustizia, Diritti, Istituzioni Democratiche

\section{INTRODUCTION}

Access to Justice is an institute of remote historical origins. Although an analytical temporal rescue about the evolution of the idea of Access to Justice goes beyond the objectives of this study ${ }^{3}$, centered on presenting the theme in its contemporary vision in Western societies, it is important to make a brief record of distant historical indications, able to illustrate the vital

\footnotetext{
${ }^{1}$ Graduado em Direito pela Universidade do Vale do Itajaí. Mestre em Direito pela Universidade Federal de Santa Catarina. Doutor em Direito pela Universidade Federal de Santa Catarina. Realizou estágio de pós-doutorado nas universidades de Perugia e Alicante e estágio sênior na Universidade de Alicante. Professor titular da Universidade do Vale do Itajaí. Coordenador e pesquisador do Programa de Pós-Graduação Stricto Sensu em Ciência Jurídica - da Universidade do Vale do Itajaí. Professor convidado da Universidade de Alicante e da Universidade de Perugia. Professor visitante do Instituto Universitario del Agua y de las Ciencias Ambientales da Universidade de Alicante.

${ }^{2}$ Doutor em Ciência Jurídica pela Universidade do Vale do Itajaí - UNIVALI. Doutor em Direito pela Università Degli Studi di Perugia - UNIPG, Itália. Condecorado com Medalha de Honra ao Mérito por relevantes Serviços Acadêmicos, no grau de Comendador, pela Academia de La Magistratura - AMAG, Lima, Peru. Mestre em Ciência Jurídica pela Universidade do Vale do Itajaí - UNIVALI. Pós-Graduado, em nível de Especialização, em Direito e Gestão Judiciária pela Academia Judicial do Tribunal de Justiça de Santa Catarina - CEJUR. Exerce o cargo de Juiz de Direito no Estado de Santa Catarina.

${ }^{3}$ For those interested, there are important historical rescues in Parosky (2008), Carneiro (1999), Mendonça, (2016).
} 
character of the concerns about the theme and to reflect the different ways in which it could be conceived in the course of civilizations.

The Code of Hammurabi, one of the earliest written norms of mankind, dating from the $18^{\text {th }}$ century $\mathrm{BC}$, already contained in the epilogue a provision that made to identify the possibility of Access to the sovereign by the hyposufficient for the resolution of problems and information about rights possible (OLIVEIRA, 2010). This prediction refers to the existence of an authority responsible for ensuring justice and resolving conflicts in a comprehensible normative order.

The document states the following:

Em minha sabedoria, eu vos refreio para que o forte não oprima o fraco e para que seja feita
justiça à viúva e ao órfão. Que cada homem oprimido compareça diante de mim, como rei que
sou da justiça. Deixai ler a inscrição do meu monumento. Deixai-o atentar nas minhas
ponderadas palavras. E possa o meu monumento iluminá-lo quanto à causa que traz e possa
ele compreender o seu caso. ${ }^{4}$ (CÓDIGO DE HAMURABI, 2011, p. 39-40).

The roots of Access to Justice are associated in doctrinal studies (LIMA, 1999) also with the biblical passage of Deuteronomy in the Old Testament, written in the 6th century BC, according to which "Judges and officers shalt thou make thee in all thy gates, which the Lord thy God giveth thee, throughout thy tribes: and they shall judge the people with just judgment"5. In this excerpt, reference can be made to the need for an impartial and equidistant third-party figure invested in the public authority to resolve conflicts of interest in societies in accordance with notions of justice.

The English Magna Carta of 1215, in turn, provides that no one will be sold, refused or delayed the Access to Law or Justice, as stated in the text that "To no one will we sell, to no one

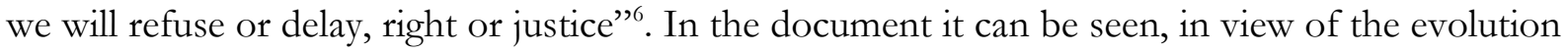
of the ideals of freedom against authoritarian conceptions of the State, and of the spelling in the second person plural, a possible embryo about the sharing, theorized today, between the State organs and the organized society in the guarantee of rights and justice. The text evolves in the logic of the previous predictions and conveys the idea that Access does not consist of a burden concentrated on sovereign authorities, on which it depends to obtain law and justice, but a common duty to achieve such ideals and the right of all to persecute before the courts, if necessary.

Contemporaneously, Access to Justice is considered an integral element of the category

\footnotetext{
${ }^{4}$ Free translation: "In my wisdom, I restrained them; that the strong might not oppose the weak, and that they should give justice to the orphan and the widow. Let any oppressed man, who has a cause, come before my image as king of righteousness! Let him read the inscription on my monument! Let him give heed to my weighty words! And may my monument enlighten him as to his cause and may he understand his case". Retrieved from https://oll.libertyfund.org/titles/hammurabi-the-code-of-hammurabi

${ }^{5}$ Retrieved from https://biblehub.com/kjv/deuteronomy/16.htm

${ }^{6}$ The text is available in the following work: Magna Carta. (2004). The great carter of English liberty granted: by king John at Runnymede on the 15 th of June, 1215. Nu Visions Publications LCC.
} 
of Human Rights ${ }^{7}$, it is found in the Constitutions of several countries (CICHOCKI NETO, 2009) and can be considered, even in the ordinances where there is no expressed normative provision, an implicit right in the Constitutional State of Law, in the democratic regime and in the systematic separation of State powers (MIRANDA, 1987), also being inherent, notably in systems linked to the Common Law family, to the due process of law clause ${ }^{8}$.

A good example is Pietro Pustrono's statement:

L'accesso individuale alla giustizia a tutela dei propri diritti costituisce um diritto umano di carattere fondamentale, che sembra avere assunto, almeno nel suo nucleo essenziale, natura consuetudinaria. Riconosciuto quale diritto costituzionalmente protetto in diversi ordinamenti, il diritto di accesso alla giustizia è ormai contemplato in numerosi strumenti convenzionali a tutela dei diritti umani e sembra rappresentare, in tali sistemi pattizi, uma delle garanzie di maggiore rilevanza. ${ }^{9}$ (PUSTRONO, 2009, p. 69).

In an initial approach to the contemporary meaning of Access to Justice, it is possible to state that an order franchises such Access to someone "when there are effective remedies available to that person to vindicate his or her legal rights and advance his or her legally recognized interests" (MULLEN, 2016, p. 69). Understood in this way, Access to Justice is one of the pillars of the rule of law and democracy (OSTI, 2016), with the aim of allowing laws and rights to be claimed by all and applied, as well as to give each citizen the prerogative of having their claims sought and their rights granted on equal terms (CONFORD, 2016).

It is a complex legal construction, which study brings together perspectives whose presence in legal systems, today, appears under various formulas. Whether as a human right on the international level or as a fundamental right in the Constitutions, Access to Justice has the proper attributes of rights of such magnitude, such as the notes of universality, unavailability, inalienability, imprescriptibility and normative force (MENDONÇA, 2016) which, within limits, characterize us. As a normative species, Access to Justice is usually presented as the norm principle $^{10}$, due to the form of its positivization and other aspects ${ }^{11}$. Even when not standardized,

\footnotetext{
${ }^{7}$ On the categorization of Access as a human right, see Câmara (2002, p. 3).

${ }^{8}$ In this regard, see Velloso (2000, p. 7).

9 Free translation: "Individual access to justice to protect one's rights is a fundamental human right, which seems to have assumed, at least in its essential core, a customary nature. Recognized as a constitutionally protected right in various jurisdictions, the right of access to justice is now contemplated in numerous conventional instruments for the protection of human rights and seems to represent, in these systems, one of the most important guarantees".

${ }^{10}$ Regarding this topic, see Cruz (2012, p. 132).

${ }_{11}$ Principles and rules are both species of the legal norms. The discussions about the elements that set them apart are rich, but they don't fit in this article. For the purposes of this work, we adopt the current according to which the distinction between norms-rules and norms-principles lies mainly in their degrees of abstraction and generality, with reflexes in the mechanisms of application. While rule norms are often circumscribed in factual assumptions that trigger predetermined legal consequences, principles, understood as the core commandments of the legal system, have open content and are noted for greater flexibility. The logic of application of the rules, because of this structural rigidity, is based on the premise of "all or nothing": either the rule applies to a particular case or does not apply, because it consecrates definitive and exclusive rights, and does not boast flexible working mechanics. The impact of the principles, on the other hand, admits consideration. Given the open structure, the principles define prima facie
} 
Access is an implicit principle that guides state and private activities towards the distribution of justice and rights (MENDONÇA, 2016). In any of the above circumstances, it emerges primarily as an authentic right, enshrined in norms, expressed or implied, contained in more closed or more open precepts, which in any case recognize it as a right, even if it has, a related and intimate, also a guarantee function, that is, an assurance profile of allowing the enjoyment of other rights in state and private spheres, jurisdictional or not. Hence it is said that one takes care of a right, but a right "funzionale o servente", paving the way to rectify the course of things when public authorities or private actors violate rights or expose them to risk. For this reason, it contributes to increase "l'adattamento dell'ordinamento ai diritti fondamentall" (OSTI, 2016, p. 11-12) ${ }^{12}$, without, however, being confused with guarantee actions or specific institutes such as habeas corpus and others.

\section{THE RIGHT OF ACESS}

The right of Access is commonly categorized as a prestational fundamental right, situated among those of the second dimension (MENDONÇA, 2016), of those who depend on state interventions (facere) for their promotion, in order to ensure the accessibility of all, on equal terms, to certain goods of life, in or out of judgment. No wonder, the theme was babitue to the post-World War II scenario, the prestigious era of welfare state philosophy (Caplen, 2016, p. 18). This prestational component may indeed be the one with the most adherence to its nature, but it does not exhaust it. Access to Justice can also be seen as a kind of fundamental freedom, in the sense that the legislature has a maximum obligation to impose vetoes (non-facere) on acts that are against its core, in order to safeguard the mechanisms of protection of rights (OSTI, 2016). In this sense it reveals itself as a first-dimension civil right, necessary for individual freedom alongside rights such as property and free contracting, differing only in that it is linked to the prerogative of protecting one's rights in terms of equality through due process of law (CONFORD, 2016). In addition, connections are also found between Access and political rights, as through acts of claim, it is possible to participate actively and democratically in public decisionmaking in the exercise of inclusive citizenship ${ }^{13}$. If this combination of elements was not sufficient, the understanding of Access to Justice is not exhausted in the relations between State

rights, prescribing, as commandments of optimization, that these rights be realized to the greatest extent possible within the existing factual and legal possibilities. In case of collision between principles, therefore, weighting is allowed, also marked by numerous parameters that do not fit this topic. On the subject, see Alexy (2008, p. 86) and Dworkin (2011, p. 39-42).

12 Free translation: "functional or servant law" and "the adaptation of the legal system to fundamental rights".

${ }^{13}$ Regarding this theme, see Abreu (2011). 
and individuals, presupposing the joint action and the sharing of responsibilities between state power and civil society ${ }^{14}$.

There is talk of Access to Justice at all stages of legal episodes (OSTI, 2016). Ever since it arouses, in one's conscience, a certain doubt or legal problem, the idea of Access assures assistance for legal advice and counseling, including pre-procedural stages. Also based on Access to Justice, if the problem persists, the right to legal assistance in extrajudicial proceedings before public and private bodies is theorized, or, where it exists, in the Administrative Jurisdiction. Nowadays, it is well understood that the idea of Access to Justice even includes private spaces for dispute resolution, provided that they are adequate and efficient, such as alternative methods (Alternative Dispute Resolution - ADR) such as extrajudicial mediation and conciliation.

The classic sense is added to all this, in an even more intuitive way, of associating it with the provision of judicial representation and the possibility of claiming rights in court, extending to ensure the proper course of the judicial process until the final phase of the judgment proceedings and enforcement (OSTI, 2016). In this sense, Access to Justice involves a double dimension (OSTI, 2016, p. 148): the private or particular one, more restricted, and the public, a broader one. The first results from the resolution, on a case-by-case basis, of conflicts of interest, enabling the enjoyment of rights or awarding solutions, in order to attend those interested in the outcome. The second comes from the diffuse effect of this problem resolution, which leads to the restoration of violated legalities and, designed in a broader scenario, provides security, enshrines rights and duties, stabilizes social and economic development, and benefits the community.

To illustrate these two meanings, the doctrinal contribution of Osti (2016) is relevant:

Risulta dunque evidente da quanto detto che l'accesso alla giustizia contiene in sé uma dimensione publica relevante e prevalente rispetto a quella privatistica: esso serve in primis' per garantire, attraverso la soluzione di singole fattispecie, il ripristino della legalità e la promozione dei diritti a vantaggio dell'intera collettività. (p. 148) ${ }^{15}$.

Also the role of interpreters and law enforcers in the national and international spectrum is paramount in defining what is to be understood as the current content and extension of Access to Justice. It is up to the courts to shape the conformation of law to the extent that controversy arises, and this definition is not linked solely to the "degree of normativity" or the "breadth of remedies available" (MENDONÇA, 2016), but also to the factual possibilities and constraints imposed in the name of the public interest and rationalization of state services. The

\footnotetext{
${ }^{14}$ Regarding this theme, see Raposo (1984).

${ }^{15}$ Free translation: "It is therefore evident from what has been said that access to justice contains in itself a relevant and prevalent public dimension with respect to the private one: it serves primarily to guarantee, through the solution of single cases, the restoration of legality and the promotion of rights for the benefit of the entire community".
} 
discussion is not without prejudice to the permanent tension between normativity and real factors $^{16}$ that inform the problem of the realization of rights. Nor is it caught in abstractions beyond the content of the norms, precedents, traditions, procedural practices, and political choices of each system. ${ }^{17}$

Given these observations on the Access to Justice, it can be said that, as stated by Mendonça (2016, p. 16), the establishment of its framework, content and meaning has been established as a function linked to the exercise of judicial activity, entrusted to the national courts when confronted with contentious cases, in establishing the meanings and extensions of the applicable normative commands, and, at the international and community levels, it is entrusted to the Supranational Courts, established as the bodies responsible for the interpretation and application of the treaties and other international and community diplomas, and the delimitation of the content of the rights enshrined in them in accordance with the political guidelines supported by the respective treaties.

For all these reasons, it can be seen that Access to Justice is one of those kaleidoscopic expressions, reflecting a concept that "draws the mind to a multitude of questions about the sources of injustice and the legal systems around the world that have developed to help provide an avenue for redressing a wrong” (Rice, \& Reisman, 2009. p. 257). It is possible to state that "Plusieurs notions entretiennent des liens étroits avec l'accès au juge" ${ }^{18}$ (DONIER, LAPÉROUSCHNEIDER, GERBAY, HOURQUEBIE, \& ICARD, 2003. p. 33), as it can be seen from the listed historical references and their elements. Due to this dispersion of meanings, the word eventually became an abbreviation for a set of situations, a series of problems and various objectives. While some adopt narrower views, others "encompass in that single word nearly every problem experienced by the judicial system" (JOHNSON JR., 1979, p. 7-8), making necessary delimitations for the apprehension of the approaches attributed here to the theme.

In view of the multiplicity of meanings of the expression Access to Justice (lato sensu) and the richness of the various aspects involved in the theme, it has already been observed that "Il est paradoxalement plus aisé de définir ce que n'est pas le droit d'áccès au juge plutôt que d'essayer de formaliser ce qui'il nest' ${ }^{19}$ (DONIER et al., 2003, p. 32).

For the purposes of this paper, Access to Justice (lato sensu) is legally viewed, in a limited

\footnotetext{
16 In this regard, it is worth remembering the notable contribution of Konrad Hesse. According to the author, although the Constitution is conditioned by the historical reality ('being'), it does not only configure the reproduction of this reality that conditions it, but it rather presents a normative force also able to conform and ordain the political and social order ('must be'), with the weakest part not always being reputed when faced with real factors of power (Hesse, 1991).

${ }^{17}$ In this sense, see Mendonça (2016, p. 158).

${ }^{18}$ Free translation: "Several concepts have close links to the idea of access to judge".

19 Free translation: "It is paradoxically easier to define what is not the right of access to the judge than to try to formalize what it is".
} 
way, in the context of accessibility to the judiciary and the rights affirmed or extracted from the legal order, which define "which of the supposed fair allows the use of force by the State" (DWORKIN, 2007, p. 122). With the same approach assumed by Tom Conford, here the "access to justice is access to legal justice it is not to be confused with justice in a more general sense" (CONFORD, 2016, 33), without the possibility to enter into philosophical concepts of justice.

Legal studies on Access to Justice sometimes deal with internal issues of positive law, more dogmatic ${ }^{20}$ and linked to the effectiveness of the judicial process as an instrument for conflict resolution ${ }^{21}$. In this sense, they tend to evaluate specific systems of procedural law, including the conditions for the exercise of the right to act, the procedural assumptions, the procedures governing individual and collective actions, appeal possibilities and others. Then, the focus is on technical-legal issues, of formal dimensions and related to the organizational modalities for accessibility to Justice, as well as the calculation of the hits and defects in a given procedural system ${ }^{22}$. There is the perspective which can be called eminently legal and procedural.

Just as often, however, the subject is researched on a broader, non-dogmatic basis, situated in the context of the role of the legal system and the judiciary in democratic regimes, including the relations between society and State, the intersections between law and politics and social justice itself. From this perspective, understanding the meaning of Access to Justice presupposes "an understanding of concepts such as separation of powers between the judiciary, executive, and legislative branches of government, the political question doctrine" (RICE, \& REISMAN, 2009, p. 257-258) and political history itself. The focus here is on the approaches to justice in general, or on the extension of the duties assigned to judges in the rule of law to guarantee to citizens. It encompasses the definition of justice and the playing field of the judiciary in democratic regimes, in interactions with other Powers (DONIER, et al., 2003, p. 32). It is, therefore, a democratic-institutional order.

Despite these distinctions, it is not advisable to completely cleave such ways of seeing Access to Justice, given the close correlation between them and the fact that procedural institutes are preordained, among other things, to enable judicial action. This interaction between the constitutional right of Access to Justice and other branches of law, in particular procedural law, often occurs and, strictly speaking, allows the "diritto costituzionale di forgiare il diritto processuale al fine di renderlo atto a tutelare in concreto $i$ diritti fondamentali, la democracia e lo Stato di diritto, nell' ambito dei

\footnotetext{
${ }^{20}$ Dogmatic analysis traditionally seeks to give evidence to basic concepts built on the logic of legal positivism. Regarding this topic, see Ferrari (2014, p. 775).

21 About that see Abreu (2008, p. 31).

${ }^{22}$ In this sense, see Magnon (2016, p. 27).
} 
sempre necessari sforzi volti all'efficientamento del sistema giudiziario" (OSTI, 2016, p. 151) ${ }^{23}$.

In the contemporary state of the art on Access to Justice there are also basically two prevailing conceptions ${ }^{24}$, which have repercussions on the way the subject is traditionally treated in foreign and national doctrines. With the expression, it is meant, in short, to refer to "la possibilità per ogni essere umano di accedere agli strumenti, generalmente giurisdizionali”, but also extrajudicial, "predisposti dall'ordinamento, posti a tutela dei propri diritti o interesi" (OSTI, 2016, p. 11) ${ }^{25}$.

The first conception takes as Access to Justice the input of a given claim, through the exercise of the right of action, in the institutionalized judicial system. The spirit is to invoke the Jurisdiction for the settlement of the conflict, the declaration and the enforcement of the applicable law (CAPPELLETTI \& GARTH, 1988), by adopting an "approccio procedimentale che si resolve con la simplice equarione giustizia/ sistema giurisdirionale" (OSTI, 2016, p. 5) ${ }^{26}$. The second conception, on the other hand, broadens the idea of Access to Justice to project it beyond the variable linked to the proposition of the action or the use of the judicial system. To this end, the whole socio-political-cultural context is assessed and the degree of legal information (FOLLEVILLE, 2013, p. 21) and citizens' level of accessibility to rights is included in the analysis, even if fruition occurs outside the judicial apparatus, whether in public bodies, in administrative proceedings, arbitration and extrajudicial mediation, or informal and private conflict resolution agencies.

In this regard, doctrine emphasizes that the

direito de acesso à justiça é revelado como fórmula de realização do acesso ao direito que congrega o direito à informação jurídica e o direito à proteção jurídica, e como expressão da prerrogativa de acesso aos Tribunais consagrada no direito à tutela jurisdicional e na garantia de que a ninguém pode ser denegada justiça por insuficiência econômica. ${ }^{27}$ (MENDONÇA, 2016, p. 158).

In the same direction, Benjamin (2011) writes that, in the strict sense, Access to Justice

refere-se apenas a acesso à tutela jurisdicional, ou seja, à composição de litígios pela via judicial. Insere-se e opera, por princípio, no universo do processo. Já em sentido mais amplo embora insuficiente, quer significar acesso à tutela de direitos ou interesses violados, através de mecanismos jurídicos variados, judiciais ou não. Num e noutro caso, os instrumentos de acesso à justiça podem ter natureza preventiva, repressiva ou

\footnotetext{
23 Free translation: "constitutional right to forge procedural law in order to make it fit to concretely protect fundamental rights, democracy and the rule of law, in the context of the always necessary efforts to make the judiciary more efficient".

${ }^{24}$ In this sense, see Abreu (2008, p. 36).

25 Free translation: "the possibility for every human being to access the instruments, generally jurisdictional", "provided by law and designed to protect ones rights or interests".

${ }^{26}$ Free translation: "procedural approach that is resolved with the simple equation justice / jurisdictional system".

${ }^{27}$ Free translation: "right of access to justice is revealed as a formula for realizing access to the right that brings together the right to legal information and the right to legal protection, and as an expression of the prerogative of access to courts enshrined in the right to judicial protection and in the guarantee that no one can be denied justice for economic insufficiency".
} 


$$
\text { reparatória. }{ }^{28} \text { (p. 6-7). }
$$

As a result of what has been articulated so far, discussions abstracted from a philosophical base, we can elaborate a concept of Access to Justice (lato sensu), in a juridical sense, as the human right in the international field, and fundamental in the internal field, commonly positive in the form of a norm-principle, or even implicit in the legal system, with its own value and also instrumental function to other rights, the content of which is complex, it allows technical-procedural and democratic-institutional approaches, as well as involving mainly state benefits and conduct of private actors, but still incorporates aspects of rights of freedom and participation, specifying (stricto sensu) the possibilities of (i) Access to the Courts for the judicial provision and (ii) Access to the Rights on extrajudicial stands, in terms of information, advice and alternative methods of conflict resolution, notions that interact with each other and have their content and extension dependent on the interpretative task of judges, on the tension between the degree of normativity of law and the existing factual and legal constraints.

In order to better clarify and deepen the categories of Access to the Judiciary and Access to Rights, which are differentiated above, it is important to broaden, to the extent and within the possible limits of this paper, their concepts and characterizations. Access to the Judiciary, so that an impartial, equidistant and independent third party (MAGNON, 2016), vested in the jurisdictional function of the State, resolves the conflict of interests and promotes the settlement and enforcement of disputed law is, by nature, the "premier des droits procéduraux", (ANDRIANTSIMBAZOVINA, 2016, p. 51) that acts as the spear and shield of all human rights ${ }^{29}$, bearing in mind that intends to activate and defend them.

Despite its obvious relevance, access to the Judge cannot be regarded as absolute and unconditioned, provided that "peut faire l'objet de limitations" (NDRIANTSIMBAZOVINA, 2016, p. 53$)^{30}$. On the one hand, there are normative and factual, substantial and procedural restrictions to the access, related to certain rights and interests that may be protected, or the collection of costs (MINIUSSI, 2014), as well as formal requirements, statute of limitations, on res judicata and other restrictions that give the institute justified and proportionate legal treatment, provided that it preserves its essential core and the soul of the right to a fair judicial process ${ }^{31}$. On the other hand, the right is not limited to facilitating the entry into the justice system or securing the Day in Court, but it involves a complex instrument of protection, with offensive and defensive positions,

\footnotetext{
${ }^{28}$ Free translation: "refers only to access to judicial protection, that is, to the composition of disputes through the courts. It fits and operates, in principle, in the universe of the process. In a broader sense, though insufficient, it means access to the protection of rights or interests violated through various legal mechanisms, judicial or otherwise. In either case, instruments of access to justice may be of preventive, repressive or reparative nature".

${ }^{29}$ Free translation: "first of the procedural rights".

30 "Free translation: "may be subject to limitations".

${ }^{31}$ In this sense, see Pacini (2008).
} 
containing the guarantees of due process (CANÇADO TRINDADE, 2011), the contradictory and the broad defense required for a fair, effective judgment, delivered in a reasoned decision and rendered within a reasonable time.

Generally speaking, access to the Judiciary is predicated as an essential right in democratic legal systems, described as the "fundamental requirement - the most basic of human rights - of a modern and egalitarian legal system that seeks to guarantee, not just proclaim the rights of all" (CAPPELLETTI \& GARTH, 1988, p. 12). It is a kind of "hinge law" in which "denial would entail that of all others" (SANTOS, 1999, p. 146). These statements are based on the logic that the progressive recognition of fundamental rights in the ages of humanity would be an innocuous advance without the mechanisms to make such rights enforceable, being the access to the Judiciary a way of proceeding to the other rights. Ensuring accessibility to the Judiciary, thus, emerges as one of the primary duties of government, including the civil and criminal areas, the first regulating private conduct and the second linked to the state duty to maintain order and peace (CAPLEn, 2016, p. 13).

Similar thinking is enshrined in foreign and national doctrines. Lenzerini and Mori (2009) teach that "l'az̧ionabilità di um diritto costituice una condizione imprescindible per garantirne l'effettività. In altre parole, il diritto di acesso alla giustizia (...) à funzionale alla realizzazzione e all'effettivo godimento dei 'diriti primari' riconosciuti" (p. 155) ${ }^{32}$. Caplen (2016) also teaches that

the importance of access to justice cannot be underestimated. It is a fundamental corollary of the rule of law because without access to justice the rule of law can be nothing more than just a concept, an ideal. If access to justice is absent, legal rights cannot be exercised and legal obligations cannot enforced. Nor can public or private bodies be challenged through the courts, or individuals brought to account. Access to justice is essential for a humane, just and civilized society. (p. 24).

Sadek (2001) points out that

os direitos são letra morta na ausência de instâncias que garantam o seu cumprimento. O Judiciário, desde este ponto de vista, tem um papel central. Cabe a ele aplicar a lei e, consequentemente, garantir a efetivação dos direitos individuais e coletivos. Daí ser legítimo afirmar que o Judiciário é o principal guardião das liberdades e da cidadania. ${ }^{33}$ (p. 7).

Fundamental rights are seen as historical achievements in the course of evolutionary

\footnotetext{
${ }^{32}$ Free translation: "the enforceability of a law constitutes an unavoidable condition to guarantee its effectiveness. In other words, the right of access to justice (...) is functional to the realization and effective enjoyment of the "primary rights' recognized".

${ }^{33}$ Free translation: "rights are dead letters in the absence of instances that guarantee their fulfillment. The Judiciary, from this point of view, has a central role. It is up to it to apply the law and, consequently, to guarantee the realization of individual and collective rights. Hence it is legitimate to say that the Judiciary is the main guardian of freedoms and citizenship".
} 
ages $^{34}$. These rights are inherent to the human person (material aspect), normally recognized as natural rights or provided for in human rights treaties, which are considered to be properly fundamental from the moment they are inserted in constitutional provisions (formal aspect), intended to promote the ideals of freedom, equality and solidarity in the relations established between the State and society and within the latter, horizontally. They are classified into dimensions or generations ${ }^{35}$ : while first-dimensional rights are linked to the political sign of freedom and demand an abstention from the State (property, political rights, criminal guarantees, etc.), the rights of the second dimension are supported by the values of equality and welfare and demand positive state benefits (health, education, security, social assistance, housing, etc.), whereas those of the third dimension embody the solidary commitment to the present and the future and demand the mutual engagement of the State and society (environment, consumer, sustainable development, etc. $)^{36}$. Alongside these classic rights are theorized, albeit with criticism of the need for such classifications, fourth-dimension rights related to political pluralism, scientific progress, biotechnology and bioengineering, as well as fifth-dimension rights such as peace, peoples' self-determination and cybernetics. ${ }^{37}$ The key idea is that all this construction would be a missing link without a Judiciary to secure such rights.

In an English work launched in the 1990s (WOOLF, 1996), resulting from research commissioned by Lord Chancellor to the Master of Rolls, the magistrate Lord Woolf ${ }^{38}$, whose content was decisive for the advent of the 1999 Procedure Rules - CPR (BARBOSA MOREIRA, 2004), it can be found the enumeration of some of the principles that, from the Access to Judge point of view, the justice system must meet to fulfill its role:

(a) be just in the results it delivers

(b) be fair in the way it treats litigants;

(c) offer appropriate procedure at a reasonable cost;

(d) deal with cases with reasonable speed;

(e) be understandable to those who use it;

(f) be responsive to the needs of those who use it;

(g) provide as much as certainty as the nature of particular cases allows; and

\footnotetext{
${ }^{34}$ Regarding this subject, see Bobbio (1992).

35 Given the complementary nature of fundamental rights, the use of the word dimensions of fundamental rights has prevailed, primarily in relation to the designative generations of fundamental rights, precisely because the terminology generations, according to the doctrine, gives the impression that the series of rights conceived in the subsequent period it succeeds and exceeds the rights previously recognized, concealing the complementarity and coexistence between rights.

${ }^{36}$ In relation to this theme, see Salles (2014).

${ }^{37}$ See Salles (2014, p. 40-41).

${ }^{38}$ Lord Chancellor is a senior member of the Government and the Master of Rolls is considered the second most important judge in the country. In this sense, see Almeida (2011).
} 
(h) be effective: adequately resourced and organised (WOOLF, 1996, p. 2).

At the same time, however, the access to the fundamental rights of freedom, equality and fraternity, and even to private and other rights, through the Judiciary, has been gaining the impression that the judicial institution is not the only or even the main institution in a democratic regime and in a scenario of legal certainty, to enable the enjoyment of such rights. Nor does it have such an institutional capacity ${ }^{39}$, for various reasons that will not be treated here by thematic delimitation. Access to Rights on a pre or para-judicial stage (RAPOSO, 1984) is also of equal importance and depends on the synergistic action of all State Powers and civil society in general ${ }^{40}$, such as the legal professions, public bodies, private sector and third sector entities. This requires social actors to share responsibilities and a network of mutual support. Under this approach, "The core of access to justice is not (...) enabling everyone to go to court, but rather to bring justice to the context in which the parties are inserted" 41 , taking into account the outcome of the solution obtained (OSTI, 2016, p. 6).

In order for extrajudicial enjoyment of rights to be possible, it is necessary for citizens to have sufficient information about their rights and duties, as well as to have adequate extrajudicial legal advice and assistance, so that they can exercise the discernment to enforce their possible prerogatives, when possible, already outside the judicial space (FOLLEVILLE , 2013). There are adequate channels for this before other Powers, regulator organs, computerized environments created by the technological revolution (TROISI, 2013) or alternative methods of conflict resolution, such as private mediation and arbitration, and work should be done to ensure that these spaces are of quality, equitable and efficient (Francioni, 2009).

Legal information and advice are essential elements for such purposes, since by generating a culture of reasonable knowledge of rights and duties, they tend to contribute, on the one hand, to avoiding illegitimate expectations that lead to frivolous actions, and, on the other hand, to encourage spontaneous fulfillment of obligations (SANTOS, PEDROSO, TRINCÃO, \& DIAS 2002), in order to foster more natural access to rights without prior judicialization. This is why Access to Rights brings with it something like "a cultural aspect (of material rather than formal meaning), walls of what can be understood as civism” (RAPOSO, 1984, p. 531).

\section{FINAL CONSIDERATIONS}

\footnotetext{
39 See Sunstein and Vermeule (2002).

40 See Rapose (1984, p. 523-543) on the topic.

${ }^{41}$ Regarding the theme, see Santos, Pedroso, Trincão, \& Dias (2002, p. 11).
} 
As final considerations, it is worth noting that this paper sought to portray the state of the art of Access to Justice (lato sensu). Two possible perspectives were identified: one legalprocedural, linked to the effectiveness of the process as a tool for conflict resolution, and another democratic-institutional, linked to the role of the legal system and the judicial institution in democratic regimes. In addition to these perspectives, two conceptions of Access to Justice were also found and differentiated: Access to the Judiciary and Access to Rights. While the first takes care of the conditions of accessibility to the courts for the judicial enforcement of rights, the latter privileges the enjoyment of rights in extrajudicial spaces, as long as they are effective. And the dynamics of Access to Justice (lato sensu) also includes the coordination between these two spaces, and it can be stated that the increase or decrease in Access to the Judiciary can influence the increase or reduction of Access to Rights and vice versa.

\section{REFERENCES}

ABREU, Pedro Manoel. Processo e democracia: o processo jurisdicional como um locus da democracia participativa e da cidadania inclusiva no estado democrático de direito. (v. 3). São Paulo: Conceito Editorial, 2011.

ABREU, Pedro Manoel. Acesso à justiça e juizados especiais: o desafio histórico da consolidação de uma justiça cidadã no Brasil. Florianópolis: Conceito Editorial, 2008.

ALEXY, Robert. Teoria dos Direitos Fundamentais. São Paulo: Malheiros, 2008.

Almeida, Diogo Assumpção Rezende de. O case management inglês: um sistema maduro? Revista Eletrônica de Direito Processual, 2011. 7, p. 289-335.

ANDRIANTSIMBAZOVINA, Joël. L'accès a la justice au sein des droits de l'homme. In J. Bétaille (Ed.), Le droit d'accès à la justice em matière d'environnement. (pp. 49-62). Toulouse: Presses de L'université Toulouse, 2016.

BARBOSA MOREIRA, José Carlos. A revolução processual inglesa. Revista de Processo, 2004. p. $118,75-88$.

BENJAMIN, Aantonio. H. V. e. A insurreição da aldeia global contra o processo civil clássico: apontamentos sobre a opressão e a libertação judiciais do meio ambiente e do consumidor. BDJur, 2016. p. 6-7. Retrieved on November 15, 2016, from http://bdjur.stj.jus.br//dspace/handle/2011/8688

BOBBIO, Norberto. A era dos direitos. Rio de Janeiro: Campus, 1992.

Câmara, A. F. O acesso à justiça no plano dos direitos humanos. In R. A. S. de Queiroz (Ed.), Acesso à justiça (pp. 1-9). Rio de Janeiro: Lumen Juris, 2002.

CANÇADO TRINDADE, Antônio Augusto. The access of individuals to internacional justice. New York: Oxford University Press, 2011.

CAPLEN, Andrew. Access to justice: the view from the law society. In E. Palmer, T. Conford, 
A. Guinchard, \& Y. Marique (Eds.), Access to justice: beyond the policies and politics of austerity (pp. 13-26). Oxford: Hart Publishing, 2016.

Cappelletti, Mauro \& Garth, Bryant. Acesso à justiça. Porto Alegre: Sérgio Antônio Fabris, 1988.

CARNEIRO, P. C. P. Acesso à justiça: juizados especiais cíveis e ação civil pública: uma nova sistematização da teoria geral do processo. Rio de Janeiro: Forense, 1999.

Cichocki Neto, José. Limitações ao acesso à justiça. Curitiba: Juruá, 2009.

CÓDIGO DE HAMURABI. (2011). Código de Manu (livros oitavo e nono) - Lei das XII tábuas. São Paulo: Edipro, 2011.

CONFORD, T. The meaning of access to justice. In E. Palmer, T. Conford, A. Guinchard, \& Y. Marique (Eds.), Access to justice: beyond the policies and politics of austerity (p. 27-40). Oxford: Hart Publishing, 2016.

CRUZ, Paulo Márcio. Fundamentos do direito constitucional. Curitiba: Juruá, 2012.

DONIER, Virgine; LAPÉROU-SCHNEIDER, Béatrice; GERBAY, Nicolas; HOURQUEBIE, Fabrice; e ICARD, Philippe. Propos introductifs. In V. Donier, \& B. Lapérou-Schneider, Béatrice (Eds.), L'accès au juge: reserche sur l'effectivité d'un droit (p. 21-50). Bruxelles: Bruylant, 2003.

DWORKIN, Ronald. O Império do direito. São Paulo: Martins Fontes, 2007.

DWORKIN, Ronald. Levando os direitos a sério. São Paulo: Martins Fontes, 2011.

FERRARI, Giuseppe Franco. Civil law e "common law" aspetti pubblicistici. In P. Carrozza, A. di Giovini, \& G. F. Ferrari (Eds.), Diritto costituzionale comparato (v. 2, pp. 775-803). Roma: Laterza, 2014.

FOLLEVILLE, Clémence de. L'accès au droit et à la justice. Paris: ESF Éditeur, 2013

FRANCIONI, Francesco. Il diritto di acesso alla giustizia nel diritto internazionale generale. In FRANCIONI, Francesco; GESTRI, Marco; RONZITTI, Natalino; e SCOVAZZI, Tullio (Eds.), Acesso alla giustizia dell'individuo nel diritto Internazionale e dell'unione europea (p. 3-44). Milano: Giuffré, 2009.

HESSE, Konrad. A força normativa da constituição. Porto Alegre: Sério Antonio Fabris, 1991.

JOHNSON JR., E. Thinking about access: a preliminary typology of possible strategies. In M. Cappelletti, \& B. Garth (Eds.), Access to justice: emerging issues and perspectives (v. 3, p. 7-8), Milano: Giuffrè; Alphen aan den Rijn: Sijthoff \& Noordhoff. 1979.

LENZERINI, Federico y MORI, Rebecca. Accesso alla giustizia per i migranti a rischio di violazione dei diritti fondamentali. In FRANCIONI, Francesco; GESTRI, Marco; RONZITTI, Natalino; e SCOVAZZI, Tullio (Eds.), Acesso alla giustizia dell'individuo nel diritto Internazionale e dell'unione europea (pp. 149-174). Milano: Giuffré, 2009. 
LIMA, G. M. O Direito fundamental à ação: o direito de ação, o acesso à justiça e a inafastabilidade do controle jurisdicional à luz de uma adequada e atualizada teoria constitucional dos direitos fundamentais. 1999. Retrieved on January 5, 2017 from http://georgemlima.xpg.uol.com.br/odfa.pdf

MAGNA CARTA. The great carter of English liberty granted: by King Jon at Runnemed at 15 june, 1215. Nu Visions Publications LCC. 2004.

MAGNON, Xavier. L'accès a la justice dans la théorie generale du droit. In J. Bétaille (Ed.), Le droit d'accès à la justice em matière d'environnement (p. 27-48). Toulouse: Pressses de L’université Toulouse. 2016.

MENDONÇA, J. J. Florentino dos Santos. Acesso equitativo ao direito e à justiça. São Paulo: Almedina, 2016.

MIRANDA, Francisco Cavalcanti Pontes de. Comentários à constituição de 1967: com a emenda n. 1 de 1969. Tomo V. Rio de Janeiro: Forense, 1987.

MINIUSSI, D. Acesso Alla giustizia in matéria ambientale e costo del processo: un difficile equilibrio. DPCE online. 2014. (S.1), 18(2), 1-15.

MULLEN, Tom. Access to justice in administrative law and administrative justice. In E. Palmer, T. Conford, A. Guinchard, \& Y. Marique (Eds.), Access to justice: beyond the policies and politics of austerity (p. 60-104). Oxford: Hart Publishing, 2016.

OLIVEIRA, P. M. de. Concepções sobre acesso à justiça. Revista Dialética de Direito Processual - RDDP, 2010. 82, p. 43-53.

OSTI, Alessandra. Teoria e prassi dell'access to justice: un raffronto tra ordinamento nazionale e ordinamenti esteri. Milano: Giuffrè Editore, 2016.

PACINI, M.. Il diritto di accesso al giudici (Commento a corte europea dei diritti dell'uomo, sez. 5., 27 luglio 2007, ricorso n. 18806/02). Giornale di diritto amministrativo, 14(7), 2008, p. 725 731.

PAROSKY, Mauro Vasni. Direitos fundamentais e acesso à justiça na constituição. São Paulo: Ltr, 2008.

PUSTRONO, P. Accesso alla giustizia e protezione diplomatica. In FRANCIONI, Francesco; GESTRI, Marco; RONZITTI, Natalino; e SCOVAZZI, Tullio (Eds.), Acesso alla giustizia dell'individuo nel diritto Internazionale e dell'unione europea (pp. 69-78). Milano: Giuffré, 2009.

RAPOSO, Moreira. Nota sumária sobre o art. $20^{\circ}$ da Constituição. Revista da Ordem dos Advogados, 1984. III(4), 523-543.

RICE, T. H. S., \& Reisman, B. L. Access to justice for tort claims against a sovereign in the courts of the united states of America. In FRANCIONI, Francesco; GESTRI, Marco; RONZITTI, Natalino; e SCOVAZZI, Tullio (Eds.), Acesso alla giustizia dell'individuo nel diritto Internazionale e dell'unione europea (p. 257-304). Milano: Giuffré, 2009. 
SADEK, Maria Tereza. Introdução: experiências de Acesso à Justiça. In M. T. Sadek (Ed.), Acesso à justiça. São Paulo: Fundação Konrad Adenauer, 2001.

SALLES, Bruno Makowiecky. Controle jurisdicional de políticas públicas em matéria de direitos fundamentais (Master's thesis). University of Vale do Itajaí - UNIVALI , Itajaí, Santa Catarina, Brazil. 2014.

SANTOS, Boaventura de Sousa. Pela mão de Alice: o social e o político na pósmodernidade. Porto: Edições Afrontamento. 1999.

SANTOS, Boaventura de Sousa; Pedroso, João. Trincão, Catarina, \& Dias, João Paulo. (2002). O acesso ao direito e à justiça: um direito fundamental em questão. Coimbra: Observatório Permanente da Justiça Portuguesa (OJP), 2002.

STAFFEN, Márcio Ricardo. Estado, constituição e juizados especiais federais. Rio de Janeiro: Lumen Juris, 2015.

SUNSTEIN, Cass \& Vermeule, Adrian. Interpretation and institutions. John M. Olin Program In Law and Economics, 2002, 156, 1-55.

TROISI, C.. Forme e Modelli di ADR. Profili sostanziali. In G. Autorino, D. Noviello, \& C. Troisi (Eds.), Mediazione e conciliazione nelle controversie civili e comerciali. 2nd ed., p. 37-78). Santarcangelo di Romagna: Maggioli Editore, 2013.

VELLOSO, Carlos Mário. da Silva. Apresentação. In J. R. Nalini (Ed.), O juiz e o acesso à justiça. São Paulo: Revista dos Tribunais, 2000. p. 7-11.

WOOLF, Lord. Access to justice: final report. By the right honourable the Lord Woolf, Master of the rolls. London: HMSO, 1996. 